María Fernández Moya Colegio Universitario de Estudios Financieros (Spain)

Paloma Fernández Pérez

Universitat de Barcelona (Spain)

Christina Lubinski

Copenhagen Business School (Denmark)

\title{
Standing the test of time: \\ External factors influencing family firm longevity in Germany and Spain during the twentieth century
}

\begin{abstract}
While most research on family business longevity focuses on how internal corporate governance issue impact resilience, the aim of this article is to foreground the relevance of external environmental factors, and to do so in an internationally comparative perspective. By historically comparing the largest family businesses in Germany and Spain in the twentieth century, we find that they differ significantly in age and ask how external factors help us better understand these variances. After analysing the institutional framework of the two countries during the second part of the $20^{\text {th }}$ century, we explore the strategic responses developed in reaction to that framework by four of the largest family businesses in the two countries. With this, we strive to capture the interdependent nature of internal decision-making processes and external environmental changes, ultimately arguing for a more holistic understanding of family business resilience over time.
\end{abstract}

Keywords: Family business; Longevity; Resilience; External environment; National determinants; Spain; Germany

Corresponding author: e-mail: mariafernandezmoya@cunef.edu

Received 26 June 2018 - Accepted 24 Feb 2019

This is an Open Access article distributed under the terms of the Creative Commons Attribution-Non-Commercial-No Derivatives License (http://creativecommons.org/licenses/by-nc-nd/4.0/), which permits non-commercial re-use and distribution, provided the original work is properly cited, and is not altered or transformed in any way. 


\section{Introduction}

This article contributes to understanding the influence of institutions and contextual factors on the longevity of large family businesses in Europe by comparing two different European countries: Germany and Spain. The choice of these two countries responds to the willingness to test the hypothesis that despite the differences in terms of national path dependent factors and in terms of patterns of corporate and business systems in both countries, it is possible to observe a common trend: the influence of institutions and institutional change in the evolution of firm strategies and survival.

In contrast with common stereotyped discourses about family business survival, often decontextualized and ahistorical, the article follows current scholarship in organizational studies that highlights the influence of contextual factors on the resilience and longevity of large family firms (Wright et al. 2014). The findings and conclusions do not contradict or deny the influence of endogenous firm-specific factors in explaining business longevity but demonstrate the need to adequately integrate institutional factors and a historical perspective in the correct understanding and analysis of business strategies and evolution.

Economic and business history is a scientific field of study that influences the approach in this article, as in this discipline external factors, such as GDP growth, economic policy and market regulation, are considered to be always influential in explaining long-term business survival. However, often organizational studies and management approaches, when it comes to the specific business form of the family firm, often marginalize the analysis of external institutional factors, for the benefit of internal firm-specific explanatories, an approach to family business survival that is often ahistorical and decontextualized. In this article, we study the case of large family businesses in Germany and Spain, which are very different types of 
business and countries, to explore how despite the sometimes extremely different features in both (i) external environmental factors and internal firm-specific factors contribute to a more holistic understanding of long-term (family) firm survival and (ii) how family businesses' reactions to changes in the external environments are crucial to understanding their resilience over time. We have selected Germany and Spain as two European countries because their business structure and economic history is profoundly different, but in both there is a strong presence of large family businesses and we had access to primary and secondary sources that allowed us to explore the questions. While our empirical results are specific to these two countries, we believe that our conceptual findings are relevant beyond them and may trigger additional research for other geographies.

In the vast and continuously growing literature, family businesses are defined in a variety of different ways (Chua, Chrisman, and Sharma 1999; Astrachan, Klein, and Smyrnios 2002). Several scholars characterize them not based on what they are in the present but rather for their ambition to survive into the future. Rather than focusing on size, legal form, or corporate governance structure, they highlight the willingness of some family-influenced businesses to preserve their family character for future generation (Casson 1999; Lubinski, Fear, and Fernández 2013; Sharma and Salvato 2013).

During the nineteenth and early twentieth centuries, family business definitions focusing on majority ownership by a family or the involvement of family members in management had many merits in countries such as Germany and Spain. These criteria captured the vast majority of family businesses in both countries (Lubinski 2010; Fernández Pérez and Díaz 2016), and were easier to study based on available firm records. However, since the last third of the twentieth century, in both countries, family business structures changed significantly 
and business families experimented with new governance forms, often driven by the need to integrate external knowledge and capital (Lubinski 2011). Many diversified holdings are controlled by family foundations or by extremely diverse financial instruments that are ultimately controlled by families (Fernández Pérez and Lluch 2016). Family businesses, in their diversity in legal forms and shareholding structures, are widespread in Europe (La Porta, Lopez-de-Silanes and Shleifer 1999; Colli 2003; Colli, Fernández Pérez and Rose 2003; Berghoff 2006). They have been the cornerstone of traditional and modern business for centuries, something which has been well recorded in public and private registers since at least the early stages of capitalism (Goody, Thirsk and Thompson 1976; Fernández Pérez 1997).

This article studies the longevity of large family firms in Germany and Spain, and pays special attention to the context that helped them endure (or not). Longevity, which we define as the successful generational transfer of strategic family influence in business, is not only a defining goal of family businesses - the consequence of their long-term vision-but also often perceived as an important proxy for their entrepreneurial success (Napolitano, Marino and Ojala 2015). Due to its importance for family firms, and its effects on the creation of wealth and employment, longevity has become the subject of an extensive literature, particularly in the field of management studies. Surprisingly, even though the topic of longevity includes by definition historical factors of analysis, most studies focus on the internal business organization and are deprived of any historical context. One of the most influential book about factors leading to successful long-term management in family firms (Miller and Le Breton-Miller 2005) does not consider the influence of changing historical conditions in explaining different factors of success for family businesses. In the last decade, 
more and more efforts have been made both in the field of family business studies (Melin, Nordqvist and Sharma 2013) and in business history (Napolitano, Marino and Ojala 2015) to study the influence of context and path dependent historical factors in the analysis of family business longevity (Colli 2011a).

We contribute to this literature by comparing the concrete situation of the largest family businesses in Germany and Spain, by analysing the macroeconomic, political and cultural factors which affected them. . Regarding our empirical research design, we set the scene by comparing the 100 largest family firms in Spain and Germany in 2005, before the crisis of 2008, and their historical development. We offer this overview to clarify the differences between business landscapes in the two countries. We use data for 2005 because we have homogeneous sources for this year that enable the comparison between the two countries. Moreover, using 2005 data helps us avoid the distortion of the last economic crisis because our aim is to see long term evolution. Analysing year of foundation, age and industry, we look for similarities and differences in the longevity of German and Spanish family firms.

Based on the results, the second part is devoted to a qualitative analysis of four selected case studies with the aim of identifying the most important external factors influencing their endurance and longevity after the II World War. In particular, we focus on the political and economic context in both countries. Given the great diversity in survival factors between industries, we limit this analysis to two selected industries-metal transformation and publishing - and a comparison of four companies, which we study based on archival material and literature. These two sectors have in common that they serve market niches and have a large number of family-owned companies in both countries. They, however, differ very much in their historical development, competitive structure and firm composition. Deliberately, we 
choose two industries that during the twentieth century faced major challenges and problems. We also include successful and unsuccessful businesses because in comparing them we can identify characteristics of the family business and see how they related to the different economic and political frameworks. Prior studies of longevity often dealt exclusively with the oldest, and therefore most successful, firms in an economy. While this is a reasonable approach, it, however, limits the scope of the analysis to the few sectors with long-term success and certain regions where companies have been founded earliest (old capitals, regions with high population density, traditional marketplaces). Our focus on industries allows us instead to take the specific competitive environment, and its development over time, into account.

The article is organized as follows: The first section discusses the term "longevity", and its interpretation in previous family business research. The next section identifies and compares characteristics related to longevity and specialization of the largest family firms in, respectively, Germany and Spain at the beginning of the twenty first century. Following a case study approach, the third section focuses on the external factors that shed light on how and why these large old family firms in both countries have been able to survive the economic and political turmoil of the twentieth century. The final section summarizes the main conclusions of the article.

\section{Longevity in family business research}

Longevity is often interpreted as a measure of success (Cassis 1997; Fahed-Sreih and Djoundourian 2006, 225). While this is true for all businesses, family or not, longevity is at the same time a subject of keen interest especially for family firms. Andrea Colli and Mary Rose $(2007,194)$ define a family businesses as a firm, which is family influenced in both 
ownership and management. As Mark Casson (1999) points out, family influenced firms differ in their "dynastic motive", i.e., the wish to keep the company within the family for generations. Many family businesses, therefore, measure their success on two scales: economic performance and long-term survival. Other rewards of longevity are the accumulation of social and human capital, the assurance of employment opportunities and stability, and the growing association of the firm's credibility and reputation with the family (Perricone, Earle and Taplin 2001, 116). If family firms achieve longevity and social recognition for their contributions to local wealth and employment, local institutions may also use the values and names of these firms to design an attractive regional and national image, which again benefits the firms. All in all, the family may gain from the firm's long-term survival but also has more to lose in case of unfavourable developments and crises, which affects both the business development and the personal reputation of the business family or families.

When family business scholars investigate longevity — often with reference to the so-called "Buddenbrooks syndrome" - they focus on the organization of the family and the firm but seldom embed the results in an economic-historical framework (Ehrhardt, Nowak and Weber 2006; Bakr Ibrahim, McGuire and Soufani 2009). A detailed literature review of the management literature on family businesses between 1994 and 2009 reveals that approximately every fourth contribution refers to a generic survival rate, arguing that only $30 \%$ of family businesses survive into the second generation, and less than $10-15 \%$ make it to the third generation (For details of the literature review and a critical review of the argument, see Stamm and Lubinski 2011). Most of the contributions referring to this survival rate sustain from giving any context for this finding. Selected ones give geographic or industry 
boundary conditions, arguing e.g. that the rate applies only to Western countries (Birley, $\mathrm{Ng}$ and Godfrey 1999, 599), to the United Kingdom (Bjuggren and Sund 2001, 11), or the United States (Dyck et al. 2002, 369) or highlighting that it refer to the manufacturing industry (Kuratko, Foss and VanAlst 1994; Mandelbaum 1994). In the vast majority of cases, the survival rate is used in an ornamental fashion in the introductory passage and taken as a universal truth.

Studies that dive deeper into the issue of longevity and survival tend to over-emphasize the internal dynamics of family businesses. Some suggest a set of standardized strategies that individual firms should follow to achieve endurance. Probably the most differentiated example is the Four-C Priorities model by Dan Miller and Isabell Le Breton-Miller (2005). It attaches long-term success to command (i.e., granting managers the right to independently make decisions), continuity (i.e., following a dynastic mission), community (i.e., developing a unifying company culture), and connection (i.e., keeping long-term relationships with stakeholders of the firm). In this model, networking and community life are considered of outstanding positive relevance for endurance, without taking into account, however, that the external environment may impose favourable but also unfavourable conditions for the longevity of family businesses. For instance, emotional attachment and community life played an important role in the continuity of many German Mittelstand firms during the nineteenth and twentieth century, despite the collapses of several political regimes and more than one economic breakdown (Berghoff 2006). However, in a different case, the excellent international and national networking of multinational private firms (most of them, familyowned) that existed in China in the first decades of the twentieth century could not play any role in the continuity of the businesses after the 1940s, as the consolidation of a communist 
regime led to the almost complete disappearance of all medium and large family businesses in that country (Fernández Pérez 2013).

Ahistorical and decontextualized approaches in the study of business endurance have been contested but more work needs to be done to fulfil the outlined agenda. Wright et al. (2014) offer a distinction between institutional and organizational factors, and ask if different family firms respond to contextual variations in different ways. Business historians are in a good position to contribute to this field of research by analysing long-term historical developments, path dependency and changing context factors. Indeed, longevity has been a recurrent topic of business history over the past few decades, leading to a series of contributions and even a special issue of Business History entirely devoted to longevity (For introduction and conceptual framework of the issue, see Napolitano, Marino and Ojala 2015). Historians have approached the topic from different directions, focusing on the impact of legal environments on resilience (Daunton 1988; Mackie 2001), on the intertwined nature of governance choices and changes in the external environment (Berghoff 2006; Lubinski 2011; Yacob 2012; Lorandini 2015; Sasaki and Sone 2015; Fernández Pérez and Lluch 2016; Sharma and Dixit 2018), on the role of family cohesion (Fernández-Roca et al. 2014) or specifically the contributions of wives (Nordlund Edvinsson 2016), and on the relationship between longevity and business performance (Capasso, Gallucci and Rossi 2015). However, as the review article by Riviezzo, Skippari, and Garofano $(2015,979)$ shows, most business history contributions study single firms ( $71 \%$ of the articles reviewed in this review) and focus on one national context (69\%). Comparative perspectives remain rare, with some notable exceptions (Colli, Fernández Pérez and Rose 2003; James 2006; Colli 2011b; Fernández Pérez and Colli 2013; Fernández Pérez and Lluch 2016). 
In this article we contribute to this line of research on the longevity of family firms, by historically comparing the largest family businesses in two European countries: Spain and Germany. These two countries provide very different institutional setups. Their analysis may help us understand the importance of contextual factors for explaining long-term family firm survival. Our analysis indicates that the internal resources of family firms need to be mobilized and adjusted to changes in the contextual environment, and not just seen as individual, technical or emotional skills, readily available and effective at all times and in various contexts. Society and its problems matter for family business survival (Colli 2003; James 2006; Fernández Pérez and Colli 2013; Fernández Pérez and Lluch 2016). Many businesses did not pass the test of time because they poorly adapted to an ever-changing environment. However, so far, few authors have focused explicitly on the question how transformations in the competitive, technological and institutional framework affected family firms' longevity in different countries. Historical contributions that do foreground the intertwined nature of family business resilience and external context tend to do so based on single-company studies and usually in one national environment. We believe that our internationally comparative approach is beneficial because it allows us to better understand exogenous factors in different national environments, and to ask how they are intertwined with family firms' organization.

\section{Long-standing family firms in Germany and Spain at the beginning of the twenty first century: A comparative approach}

According to the Family Business Network monitor, and the Family Business Index of 2017, family business is the most common form of ownership and control in Europe. ${ }^{1}$ Family businesses represent $79 \%$ of all German enterprises and $85 \%$ of Spanish firms compared to

\footnotetext{
${ }^{1}$ Available at http://www.fbn-i.org, http://familybusinessindex.com/
} 
$91 \%$ in Finland, $83 \%$ in France, $79 \%$ in Sweden, $73 \%$ in Italy, $65 \%$ in the UK, and $61 \%$ in the Netherlands. Regarding total employment in Europe, they account for between 31 (in the UK and the Netherlands) and 61\% (in Sweden) (Tàpies 2011). Despite the obvious variances between countries, there are only few historical studies—such as Colli, Fernández Pérez and Rose (2003), James (2006) and Colli (2011b) — that start to explicitly compare the national settings for family firms in different countries over time.

We add to this line of research by comparing Spain, a Mediterranean country and industrial late developer, with Germany, the fastest growing economic power in Western Europe, after the Second World War. For Germany, we used the list of the top 500 family owned corporations published by the Institut für Mittelstandsforschung and completed the data with information from websites and company publications. For Spain, we used the list of the 100 largest family firms in 2005, published in Tàpies (2009), and completed the database with data from Actualidad Económica and companies' websites. ${ }^{2}$ At first glance and based on the percentages of family firms today, one would assume that long-term family ownership played a more important role in Spain than it did in Germany. In line with Alfred D. Chandler Jr.'s (1977; 1990) ideas regarding the advances of large corporations in the world, one may think that the success of the big corporation has meant a sharp decline in family ownership in Germany in the second half of the twentieth century, whereas the late convergence and integration of Spain in the world markets would have resulted in a country with many old family firms. However, this assumption is proven wrong if we compare the 100 largest family firms in both countries in 2005. The figure below shows quite the opposite: on average large

\footnotetext{
${ }^{2}$ A comparative overview of the longevity of the largest 20 family businesses of 17 countries including developed and developing economies in Fernández Pérez 2015, where findings also indicate that in Germany and in Japan despite war destructions of the 20th century family firms are today older than in South America or Spain not so negatively affected by destructive World Wars.
} 
and relatively old family firms dominate in Germany, and relatively young family firms are typical for Spain's large family businesses.

Figure 1. Top 100 largest family businesses in Germany and Spain by year of foundation (2005)

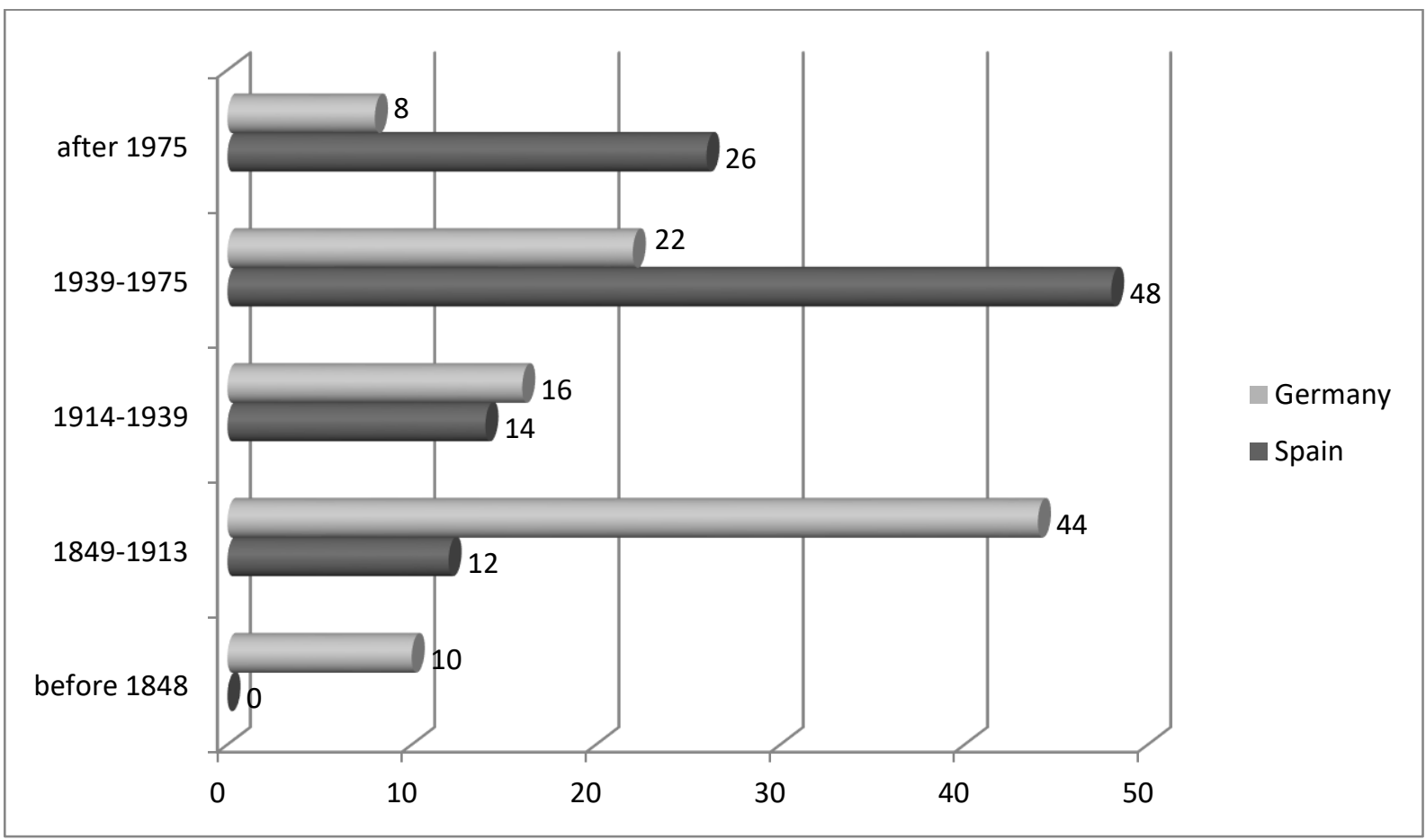

Source: Author's own elaboration.

In Germany, the majority (54\%) of the top 100 largest family firms in 2005 was founded before the I World War with a peak during the years of the "Gründerboom" (a boom of new businesses founded) in the early 1870s. Another $16 \%$ started their activities in the inter-war period. Only $30 \%$ in total were founded after 1939 and only a very small percentage of eight percent after 1975. That means a strong resilience of family firms created during the crucial years of consolidation of the German State and during the key years of dissemination of technologies and pioneering firms of the Second Technological Revolution in Germany. In Spain, the majority of businesses (74\%) clearly derived from the Post-Franco-Period after 
1939 (the year of the end of the Spanish Civil War). Only 12\% of the largest family firms had already been in businesses before 1913 (none before 1848), another 14\% started their activities between 1914 and 1939.

In 2005, the top 100 family firms in Germany were on average 83 years old, whereas in Spain the average age was significantly lower; 41 years. A comparison with the average longevity of the largest 25 North-American family firms (82 years) reveals a strong similarity of Germany with the U.S., and suggests that an important reason behind the old age of German and U.S. family firms may have been an early development of large firms specialized in technologies of the Second Industrial Revolution, and a relatively long and stable protection of these industrial firms, which did not occur in the case of Spain. Institutional external factors were, together with pioneering technological waves of innovation, two driving external factors that seem to have influenced an average greater longevity in Germany and in the US in comparison with Spain. Technological innovations provide market leadership to pioneering companies. Institutional protection is more difficult to be analysed and measured, but could have interrelated effects with technological innovativeness to provide long-term effects in longevity capabilities of firms. The comparison of German and Spanish family firms suggest that, alone, institutional protection is not enough and needs to be connected with pioneering technological and scientific innovative organizations. In the case of Spain, for instance, protection via relatively lower taxation policies over the $20^{\text {th }}$ century took place to support largest industrial companies regardless of the political parties in power, often with corrupt practices and bribery, but lack of competitiveness in new technological and market contexts made some of the biggest business groups led by families In fact, two important reasons behind the relatively young age of the oldest and largest Spanish family firms in 2005 
are (i) bankruptcy very related to lack of productivity and competitiveness, and (ii) transformation into diversified financial investment funds between the 1970s and the 1990s. Bankruptcy, first, affected hundreds of small and medium-sized Spanish family controlled industrial firms after the industrial crisis of the 1970s and 1980s, for two combined reasons: lack of technological and organizational competitiveness, and loss of institutional protection with changing political. Those decades witnessed a complex political transition from dictatorship to democracy in Spain, with new and very high taxes to Spanish firms and wealthy individuals (who had benefitted from very low taxation over centuries). This led, as said, to a wave of industrial bankruptcies in the 1980s. In the 1990s, new changes of legislation in Spain provided important tax reductions for the creation of family-controlled financial funds and other financial instruments, with new legislation promoting family offices and SICAVs. Both the bankruptcies of the 1980s, and the financialization of the 1990s, contributed to stimulate the legal disappearance of family firms from traditional Spanish registers of firms, and to the creation of new family-participated or family-controlled financial investment funds, which are difficult to track and measure (Fernández Pérez and Hernández 2010).

German industrial firms, pioneering technological and scientific innovations, and keeping institutional protection despite change in political actors, increased their scale and scope before the I World War while strongly keeping - somewhat in opposition to what Chandler has suggested - family ownership and control (For this critique see also, Fear 2005). Most of the Spanish companies (48\%) were founded between 1939-1975, during the Franco regime, when the industrialization of the country primarily took place. In Spain, there were family firms in capital intensive industries before 1939, like in the automobile and the chemical 


\section{Journal of Evolutionary Studies in Business}

industries, but Franco's regime established a tough public intervention in capital intensive industries after 1939 that stopped one pathway of growth in scale and scope in very important private firms. Due to this strong interference of the public sector, and in contrast to Germany and other Western European countries, even some of the oldest industrial family firms in Spain are relatively young, and are specialized today in sectors such as food and beverages and in those typical of the distribution revolution of the second industrial revolution (wholesale distribution) (Fernández Pérez and Puig 2007; Fernández Pérez and Diaz 2016). The argument that German family firms tend to be older is also supported by Goto (2006, 521), who claims that the total number of long-lived firms is by far largest in Japan, however closely followed by Germany. Other European countries, such as the Netherlands, France, Austria, and also Spain give home to a significantly smaller number of long-lived firms.

Figure 2. Top 100 largest family firms 2005 by industry

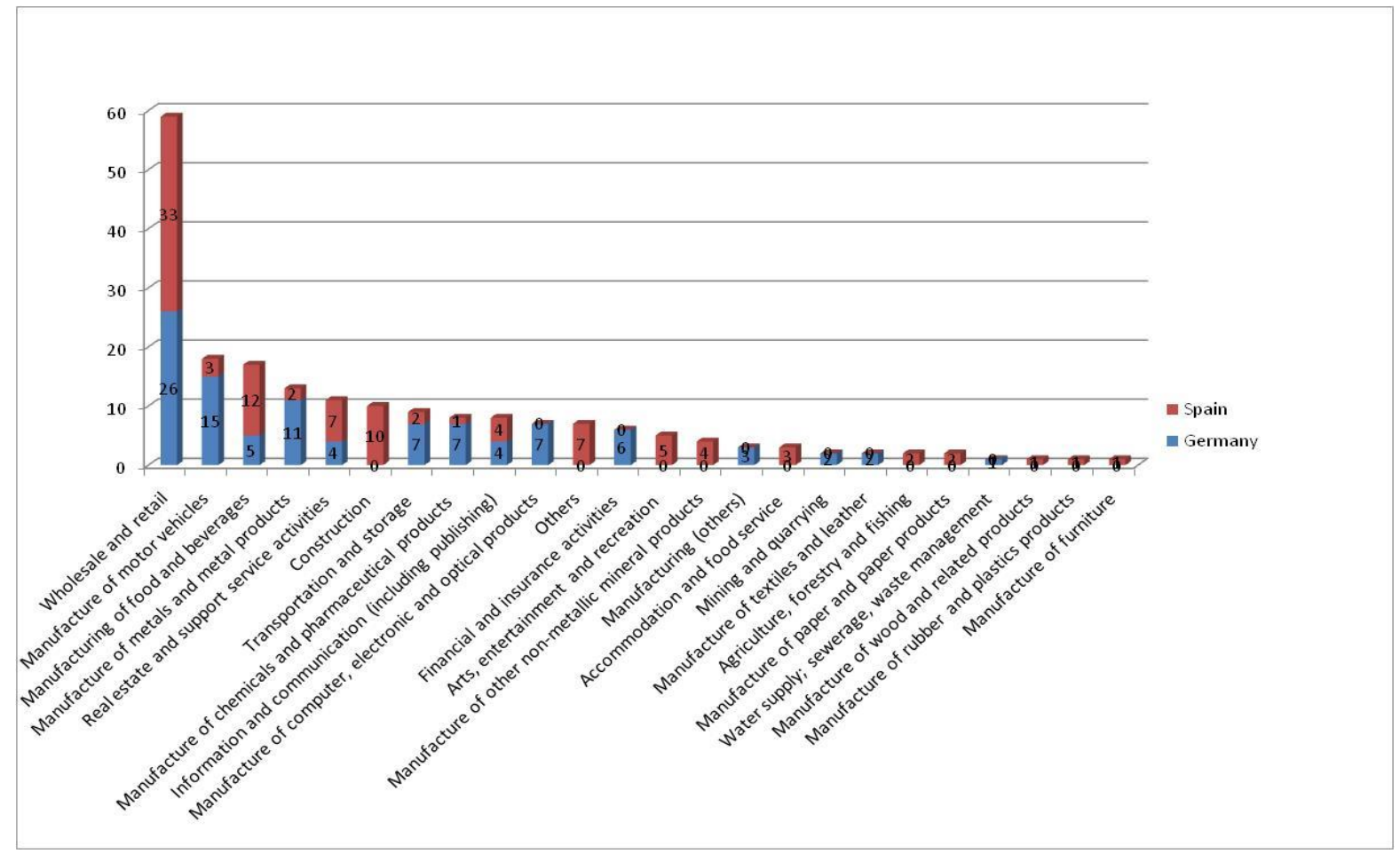

Source: Author's own elaboration. 
This article asks how these differences can be explained at the micro level and not just at the macro level, and unlike most contributions to longevity, research focuses on the external environment and how particular family businesses responded to the opportunities and challenges of such broader environments over time. To get to a level of empirical depth, we focus our analysis on individual case studies rather than studying macro-economic data in isolation. We thus explore family firms' responses to external context and change, to better understand the impact of external environments on family businesses' longevity.

\section{Understanding Longevity: Four Case Studies in Context}

As we want to understand the differences in longevity, we focus the qualitative section of this article on four case studies (two for each country) from two sectors, metal transformation and publishing. We have selected these four cases because of the availability of historical sources and their long-term existence over at least eighty years as family-influenced firms. We consciously included both successful and unsuccessful family firms to counter the otherwise common success bias. Another important selection criterion was to have companies from two industries, publishing and metal transformation, because it allows us a cross-national comparison of companies in the same industry. We analyse the four cases based on company and family archives (Bagel, Deckel, public archives (Planeta and Roca), as well as published secondary sources. Metallurgical industries and publishing industries have been selected, also, because historically metal companies have enjoyed a very old protection from military and civil authorities for the strategic implications metal production has, in times of war, but also for their capacity to employ thousands of workers for heavy industries and infrastructures, which has a political interest in election times. Publishing companies, however, have less interest for policy makers, they tend to create fewer job positions. For these reasons both 
sectors are interesting to test how in individual family firms external factors like technological change and institutional protection may have had a similar, or a different, influence in longevity of these firms. In metal transformation we analyse the Spanish manufacturer Roca Corporación, a global leader in metal and ceramic equipment for the bathroom; and the German machine tool producer Deckel, famous for its drilling machines. In publishing, we compare the Spanish publishing group Planeta and the German publisher A. Bagel Verlag, part of the printing and publishing group Bagel. All four case studies have in common that they remained family influenced for several generations. While Roca (founded in 1830) and Bagel (founded in 1801) have both been family-owned and -controlled since inception, the publishing company Planeta was bought by the family in 1949, which held and managed the firm ever since. The Deckel company, by contrast, was founded in 1903 and remained familyowned and -controlled until 1991 when the family decided to sell to an external investor. The family business literature claims that less than $30 \%$ of family firms survive into the second generation and fewer than $15 \%$ make it to the third (Ward 1987, 248).

Table 1: Overview of case studies, 2001

\begin{tabular}{|c|c|c|c|c|}
\hline & \multicolumn{2}{|c|}{ Spain } & \multicolumn{2}{|c|}{ Germany } \\
\hline & Planeta & Roca & "Bagel & Deckel \\
\hline Year of foundation & 1949 & 1830 & 1801 & 1903 \\
\hline Sector & Publishing & $\begin{array}{l}\text { metal and ceramic } \\
\text { transformation }\end{array}$ & Publishing & $\begin{array}{l}\text { metal } \\
\text { transformation }\end{array}$ \\
\hline Family control & $100 \%$ & $100 \%$ & $100 \%$ & $\begin{array}{l}\text { The family sold the } \\
\text { company in } 1991 \text {. }\end{array}$ \\
\hline Family in business & $\begin{array}{l}\text { Lara Family. } \\
\text { Second Generation }\end{array}$ & $\begin{array}{l}\text { Roca Family. } \\
\text { Fourth Generation }\end{array}$ & $\begin{array}{l}\text { Bagel Family. } \\
\text { Seventh Generation }\end{array}$ & $\begin{array}{l}\text { Deckel Family. } \\
\text { Third Generation }\end{array}$ \\
\hline $\begin{array}{l}\text { Sales 2008, } \\
\text { thousand euros }\end{array}$ & 1,642 & 1,721 & $\begin{array}{l}\text { No data available } \\
\text { (Printing only: 166) }\end{array}$ & 1,938 \\
\hline Stock exchange & Private company & Private company & Private company & $\begin{array}{ll}\text { Publicly } & \text { quoted } \\
\text { since } 1973 & \end{array}$ \\
\hline
\end{tabular}

Source: Author's own elaboration. 
This would suggest that our case studies are particularly successful in realizing longevity; however, as discussed in the literature review section, this survival rate is questionable on the grounds that it ignores the impact of the external environment on resilience.

We studied the historical evolution of each of these four case studies based on the question how the external environment influenced the firms' development and resilience and how the firm responded to changes in the environment. We then compared all four case studies with each other, and ultimately identified three sets of external factors that emerged as crucial for understanding these companies' resilience over time: (1) the economic development at the industry level, (2) the political context at the national level, and (3) inheritance law regulations.

Figure 3. Per Capita GDP 1950-2008 (1990 International Geary-Khamis dollars)

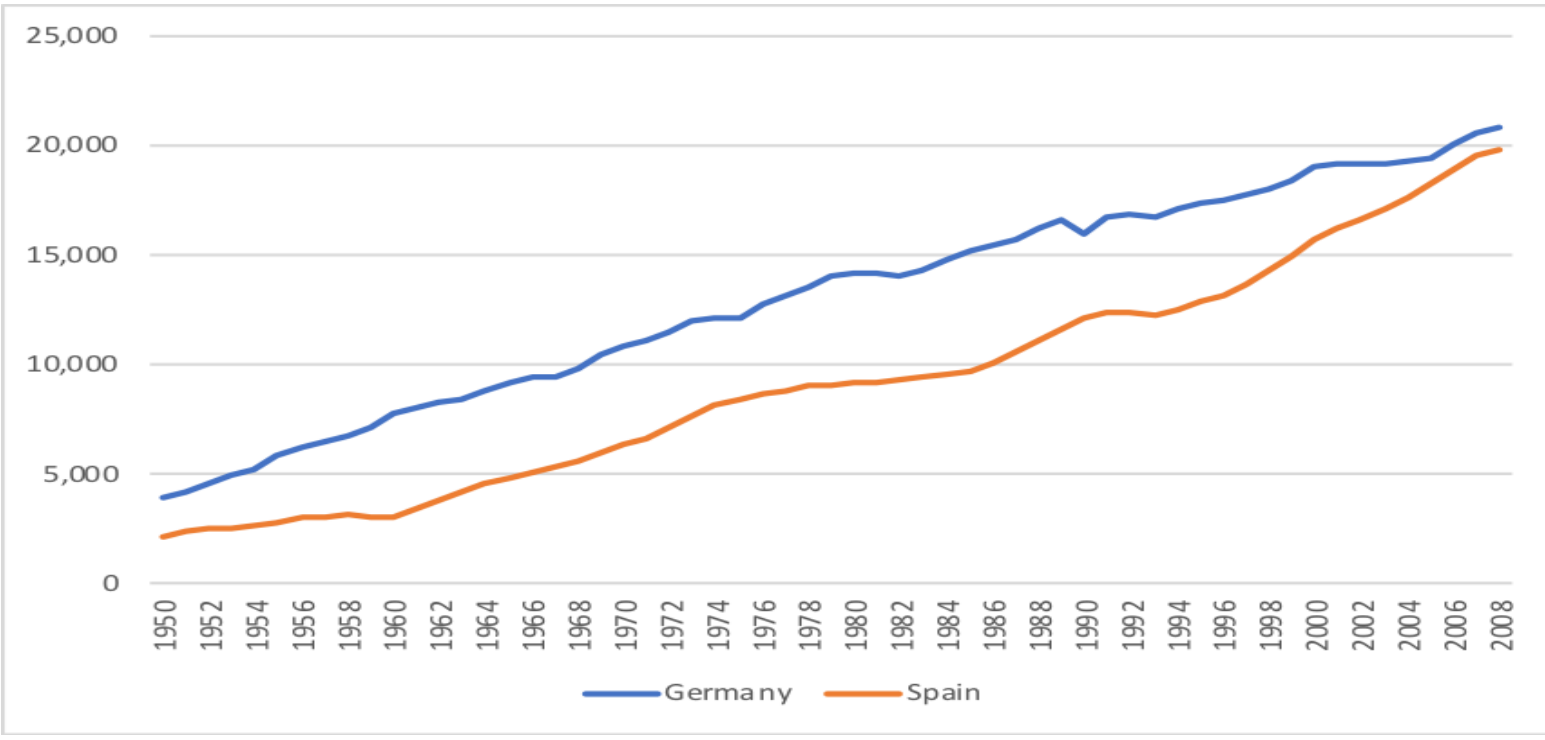

Source: Angus Maddison. Available at: http://www.ggdc.net/maddison/oriindex.htm

Economic Development

The general economic context, in which both Spanish and German family businesses found opportunities for survival during the second half of the twentieth century was mostly favourable; according to macroeconomic indicators, such as GDP growth (see Figure 3, 
productivity, investment, improvement of human capital endowment, and the parallel growth of entrepreneurial benefit and workers' income rates.

\section{Metal Transformation Industry}

The metal transformation industry in Western Europe expanded tremendously after the end of the Second World War. It was the engine for economic growth and contributed to the increasing GDP growth rates in Spain and Germany respectively (Schulze 1999). Some common factors add to explain this expansion, particularly the need to cover the technological gap with the United States and the opportunities related to it; the strong demand of the transport and construction industries; and the positive effects in trade and finances of the Bretton Woods agreements. In both countries, the industry had a significant number of family-owned companies. Production was frequently heterogeneous with products in many different types and sizes. Therefore, companies often served niche markets, like the two cases discussed here, the German firm Deckel and the Spanish manufacturer Roca.

Deckel (Friedrich Deckel München 1978) and Roca realized enormous growth rates from the end of the Second World War to the beginning of the 1970s. In the Federal Republic of Germany, metal transformation was one of the leading sectors of the post-war economy (Baumann 1965). Technological innovations were fundamentally initiated before the war but accelerated its application for mass production after the war, at home and abroad, due to the positive technological gap with other countries in the sector. In the years directly after the War, most of the German capital goods industry was under the control of the Allied that supported West-Germany in regaining its economic strength. The Korean War (1950-52) triggered a boom in demand, which in particular increased the export quota and even led to 
supply shortfalls in German companies (Giersch, Paqué and Schmieding 1994). ${ }^{3}$ The industry realized growth rates above average and settled in a position as world leader. In this favourable context, Deckel raised its annual turnover and number of employees significantly (Friedrich Deckel München 1978, Krogh 1987). It mainly produced high quality special purpose machines sold at premium prices. In this phase, innovation primarily consisted of adapting the conventional technology to different machine models. Economies of scale were thus very limited because of the sheer variety of models and the absence of modularization. To nevertheless increase the economies of scale, Deckel extended its target markets. The company's main growth strategy at the time was exporting. Up until the mid-70s, Germany was the clear export leader for machine tools with exports accounting for over $30 \%$ of world trade (Wieandt 1994).

The Spanish manufacturer Roca was similarly successfully both in realizing profits and in adapting to the market challenges. Technological innovation had also, as in Deckel, taken place before world war II, but not with own patents and engineering but with North American knowledge transfer from a US corporation with whom they had had a joint partnership before 1939. After 1939 new laws during the military dictatorship forced foreign owners of Spanish companies to reduce or plainly sell at below the market prices their shares in Spanish companies, thus forcing legally real property expropriations. Due to this legal change intended to protect the Spanish metal industry Roca's North American owners had to abandon the company with great losses, and the Spanish family Roca could buy their shares at a convenient price and fully control the firm. A firm with a new factory with brand new US technology that had been brought by the formerly dominant North American partners. With

\footnotetext{
${ }^{3}$ According to these authors, the Korean War acted like a Keynesian stimulus. A different opinion was voiced by Temin (1995).
} 
this extremely protectionist framework, between 1939 and 1975, the company's main growth strategy was to increase relatively safe from foreign competitors their share of the domestic market in metal and ceramic sanitary equipment, through a combined strategy of acquisitions of firms with problems, superior technological know-how or commercial networks, and a strategy of closeness with the political authorities of the Industry and Economy Ministries in Madrid. Both companies financed their growth strategies internally and thereby allowed the two family businesses to remain independent.

This favourable context, however, changed during the 1970s. With the collapse of the Bretton Woods agreement, a system of free currency convertibility came to an end (Eichengreen 2008). The oil price crisis of 1973 and 1979 raised the costs for energy, which had a significant impact on metal transformation companies. Moreover, international competitors from low wage countries gained market shares within Europe. Deckel and Roca had to adapt to the changing framework by reorganizing the company, rationalizing production and reinforcing internationalization. The Spanish Roca family reacted in stepping back from direct management and allowing an in-house trained outsider to professionalize the management and lead a strong internationalization process that had already started with opening of subsidiaries in France and Portugal in 1970. In Spain, after 1975, a new democratic regime, the integration in European and world markets, and the increasing international competitors made internationalization and professionalization of management two imperative needs. Between 1973 and 2000 there was a big crisis in the Spanish metal mechanic industries, with new firms in the landscape that bought many old firms in decline (Ortega and Hermosilla 2002). During these critical times, the family managed to make important changes in the internal organization to adapt to changes linked to the new wave of globalization and the new 
democratic parliamentary system established in the country which increased protection to workers in terms of salary conditions and right to strike. A new management organization was able to deal with the new power of unions, European integration and competition, Asian lower prices in Europe. Through proactive internationalization strategies and mergers and acquisitions in key markets, with expansion of sales in Germany, United Kingdom and Italy in 1990, the construction of a factory in China in 1999, and the acquisition of factories in Poland and of a global firm from Switzerland (Keramik Laufen, the fourth largest world manufacturer of sanitary porcelain tiles) also in 1999. Acquisitions worldwide have been the key strategy of entrance in other markets since 2000: Croatia, Romania, Malaysia, India and Brazil. ${ }^{4}$ Important labour force reductions took place while at the same time a policy of importing technology from abroad increased in order to have a diversified and innovative number of products and services in the two areas of metal and ceramic equipment for bathrooms.

The family, since the beginnings of the 1830s, had grown large in members, and the crisis made them see the need to unify the control of the different factories in the country under a professional non-family member, well acquainted with the workers, the factories, and the values and moral codes of the family. This new non-family CEO, a 29 years old industrial engineer close to the Roca family, a man the Rocas highly trusted, was Salvador Gabarró, who pushed forward an ambitious strategy of internationalization and also of networking in key professional and entrepreneurial associations between 1974 and 2000 (the year another young non-family CEO, José Miguel Roca, took over the control of the company). The domestic market remained extremely important for the sales of the company, and more during

\footnotetext{
${ }^{4}$ http://www.roca.com/our-history (accessed 4 October 2010)
} 
the real estate and construction bubble of the 1990s, which implied a sustained high demand for its products. A combination of first steps towards internationalization in the 1970s, continued investment in technology imports and innovative marketing and professional management since the 1980s, allowed survival of the family business with a professional non family CEO Roca has been able to overcome difficulties and maintain leadership in its market niche in Spain and has followed a process of acquisitions of major competitors and technology leaders in the world that has given the company world leadership in the field of manufacturing sanitary equipment. Roca's sales in 2005 were of 1,669 million Euros, with more than 20,000 employees. It was therefore one of the largest Spanish private firms in its sector of activity, very internationalized $(50 \%$ of sales, 40 factories abroad, and commercialization structures in 88 countries of four continents in 2005), and world leader in the manufacturing of sanitary equipment after a strategic and continuous process of mergers and acquisitions at home and abroad that started in 1970, which helped much needed technology transfer at a global scale. ${ }^{5}$

Deckel was hit hard by the recessions following the oil price crises and similarly to Roca started taking in external managers and capital. When the German post-war reconstruction process eventually came to an end, the company experienced severe slumps in sales. ${ }^{6}$ More or less simultaneously product innovations significantly transformed the existing market structures in the machine tool industry. Since the mid-1970s Deckel invested heavily in new technologies, such as numerical Control (NC)-systems and computer-based numerical control-systems (CNC) for their machines. The percentage of produced CNC-machines rose

\footnotetext{
${ }^{5}$ http://www.oriolamat.cat/files/roca_radiadors.doc (accessed 8 June 2010).

${ }^{6}$ BWA N06-005 to 017 Geschäftsbericht der Friedrich Deckel AG 1978-1992.
} 
from $19 \%$ in 1978 to $83 \%$ in $1986 .^{7}$ This development forced the family firm to invest in microelectronics and increased the demand for highly qualified workers (Spur 1991; Bähr 2001). To raise the necessary capital for these investments, the company ultimately went public in 1981; an unusual step for a family business interested in keeping control. However, the family issued, among others, "preference shares" without voting rights, a strategic choice designed to allow the family to keep control, while opening the business for external investors (Schürmann and Körfgen 1987). ${ }^{8}$

While Deckel was struggling with the reorganization of the company, new competitors, in particular from Japan, gained market shares and made Deckel's niche increasingly unprofitable due to price reductions and shifts in demand. Following major losses at the end of the 1980s, the company reorganized and sold a vast number of non-core businesses thereby reducing its workforce from 2,450 in 1989 to less than 1,000 only three years later. ${ }^{9}$ In an attempt to realize greater economies of scale and scope, the firm strove for a stronger modularization of machine tool parts and simplified its products. While the company had hitherto focused on flawless engineering and generous customer service, Japanese competitors were more successful with their aggressive pricing strategies. Deckel sliced manufacturing of its own components in half, breaking with a treasured practice of the family firm aiming at guaranteeing quality. They also put a new focus on marketing and product development and cooperated with partners and competitors. However, sales continued to fall. In 1989, Deckel's losses accounted for DM 45 million at an annual turnover of DM 482 million. The turnaround-program designed in cooperation with the consulting firm Roland Berger triggered major cost-cuts. Despite these efforts, the firm did not survive the biggest

\footnotetext{
${ }^{7}$ BWA N06 011 Geschäftsbericht der Friedrich Deckel AG 1985, p. 11.

${ }^{8}$ BWA N06-043 Ausgabe von stimmrechtslosen Vorzugsaktien 1986.

${ }^{9}$ BWA N06-1 Verschmelzung der Friedrich Deckel AG mit der MAHO AG 1993.
} 
crisis in the industry since the Second World War (Lamparter 1993). In 1991, the Deckel family decided to sell its shares to Walter Eder, a Munich based manufacturer of excavators, thereby ending the family influence (Anonymous 1994).

\section{Publishing}

Compared to metal transformation, the publishing industry developed in a similar manner but at reduced speed. The Spanish publishing house Planeta was bought by the family during the Franco dictatorship. The growth of Planeta in Spain in the first decades (1950-1970) has been built upon three products: translations of North American best-sellers; Spanish literature publicised through the famous Planeta Prizes for Literature, created in 1952; encyclopaedia sets sold on a credit system. Regarding the markets, Planeta grew in the 1960s mainly through international expansion. It was the era of the so-called "exporting boom", and the Spanish companies realized $50 \%$ to $60 \%$ of their revenues in the Latin American markets, taking advantage of the pro-Franco government measures of support. Affiliates were opened in Mexico (1965), Colombia (1965), and Argentina (1966). But the reason for the leading position in international rankings was a growth strategy developed from 1980s onwards, focusing on three variables: internationalization (Latin America and Europe), diversification (literature, textbooks, communication), and vertical integration (print, distribution, and libraries) (Tàpies and Fernández-Moya 2012)

The decade of the 1980s marked the beginning of the concentration process of the Spanishlanguage publishing sector. This relatively late concentration is a major difference compared to the German publishing industry, in which a strong concentration tendency can already be noted for the 1960s (Fernandez-Moya 2012). In that framework, Planeta developed an extraordinary expansion process basically through a strategy of growth fed by acquisitions, 
like in Roca Corporación. Planeta purchased prestigious brands in the Spanish speaking area, with a solid market implantation, in order to consolidate its internalization and diversification process. Sector concentration would increase in the 1990's and the first years of the new century. As a result of the concentration process, Grupo Planeta consolidated as the largest Spanish publishing company (Fernandez-Moya 2012). The success of the Spanish company can be symbolized with the creation of the group: Grupo Planeta, and this transformation included profound changes in the organizational structure. According to its turnover and presence overseas, the company developed into a large multinational, which triggered further changes in the internal organization discussed below.

Similar to Planeta, the publishing company Bagel experienced high growth rates during the 1950s and 60s (Lubinski 2010). At that time, the German publishing industry was faced with a wave of concentration. Bagel as one of the medium-sized publishers and a typical German Mittelstand firm relied on "organic" growth strategies. It reinvested profits into the business, but avoided the integration of external investors and venture capital. Bagel had for long used the strategy of vertical integration combining activities in publishing with paper producing and printing since the late $19^{\text {th }}$ century. The prosperous 1960 s gave it the opportunity to diversify into other related industries mainly by acquisition activities. Bagel, however, focused on less capital-intensive sectors in order to remain independent as a family firm. ${ }^{10} \mathrm{In}$ all sectors, the company focused on the high-end-segment putting a special focus on quality and specialized goods, such as school books and literature in publishing, safety prints (stamps) in printing, and special thin papers in paper production. This mixed strategy of diversification and specialization allowed the business to explore new promising markets all

\footnotetext{
${ }^{10}$ Bagel-Archives 236-2 Peter Bagel's own description in: Reden und Ansprachen Peter Bagels, 1801-1976, 175 Jahre Bagel, 6 Generationen.
} 
the while remaining a high quality producer. The number of employees rose from 900 in 1951 to 2,000 in 2006.

With the changes in the economic and political framework in the 1970s, Bagel encountered more and more difficulties. The changes in technology and workplace organization triggered rationalizations in the entire industry. In 1972, the publishing house self-analyzed that the business was stuck in an unfortunate middle-size; it had outgrown the small-size organization but was not in the position to compete with large German or international publishing houses. ${ }^{11}$ As an integrated printing and publishing company Bagel experienced first-hand the degrading industrial relation in the printing industry in the mid-1970s, which endangered the harmonious employer-employee-relationship in the family firm. ${ }^{12}$ Struggling simultaneously with the dangers in the macroeconomic development and at the level of the workplace, Bagel reinvented itself more than once during the last three decades. It reorganized its activities, stepped back from paper production, diversified into label printing and set new priorities in its publishing activities. In the process, the family, however, managed to guarantee its independence and continued to this day to influence both management and ownership.

\section{Political Context}

The second exogenous factor for longevity largely ignored in longevity research so far is the political context. Here important differences between Germany and Spain can be noted. First, the State was in general an ally of private businesses in Germany during the second half of the twentieth century, and a disturbing competitor and sometimes evens an enemy of private businesses and free market forces in Spain during the same decades.

11 Bagel Archives 192-5 Jahresberichte der Geschäftsführer, 1972 August Bagel Verlag.

12 Bagel Archives 192-5 Jahresberichte der Geschäftsführer, Lagebericht über das Personal- und Sozialwesen in der Zeit vom 1.7.1975 bis 28.2.1976. 
In Spain the end of the autarky period of the 1940s that followed the Civil War of 1936-1939 dramatically isolated Spain from its former path of internationalization and industrialization. The military regime organized the economy in the 1940s as a military endeavour, in which strategic inputs and activities had to be under State control (energy, iron and steel, chemicals, transportation equipment). Since 1941 the State started a public industrial holding named INI (National Institute of Industry, similar to the Italian IRI) which radically reduced private businesses from what the State considered strategic national interests (metal mechanic industries, energy, telecommunications, transport industries). Therefore, technologically complex firms with high requirements of knowledge transfer and long-term capital investments could only seriously be developed in Spain by the public holding I.N.I. (National Institute of Industry). In publishing, the new government exercised its control through an iron-fisted censorship in the heavily regulated sector (Martinez-Martín 2015). To manage official politics of the sector, the Government founded in 1941 the Instituto Nacional del Libro Español (INLE). Five years after, the Government passed of the Book Protection Law of 1946 (Fernandez-Moya 2009). The Law established a number of theoretical measures which proved difficult to apply in practice (General Administration Archive). The Spanish publishers began to talk with the Spanish government and pressurised for support. The political framework was ideal; the government was initiating a new phase of economic planning, and designated some sectors as priority (not only the publishing sector), which were aided through a variety of measures. From this moment on, a group of norms were passed, which aimed to provide a solution to the problems of the period: paper importation, exemption from the Utility Tax, tax deductions, finance facilities and the reform of export insurance policies. The two major incentives for the publishing sector were export, tax 
deduction and preferential finance (Fernandez-Moya 2015). The trajectory of Planeta exemplifies the effects of this policy. The company began an international strategy, focused on the Latin American markets, thanks to the help of this public support (Banco de Crédito Industrial Archives).

Until 1959, the State created many obstacles for survival or growth of private enterprises, and made every effort possible to discourage exports. The State restricted access to foreign currency (needed for imports), electricity, and raw materials (scarce due to commercial autarky) to private firms in consumer goods industries, which constituted the backbone of family owned businesses in the country. Businesses suffered the consequences of this new economic policy. The State was very interventionist, reduced free competition in sectors of the II Technological Revolution (modern steel production, car industry, ICTss, chemistry, energy), allowed some freedom to private firms in low added value industries and services, and protected in different ways the domestic market from foreign competitors. The year 1959 marks a turning point in this economic policy: the dictatorial Spanish regime started to liberalise the economy. Franco government in the early 1960's also initiated a new phase of economic planning aimed at the country's complete industrialization, which supported family firms and groups in various sectors like the ones analyzed in this article. Since the late 1970s, privatization and internationalization changed the legal rules of the game and the opportunities for private firms in general, and family firms in particular. The arrival of democracy (1978) and Spain's incorporation into the EEC (1986) also affected the strategy of the Spanish companies. Planeta, for example, began to priorities the European markets, and its exports to the Eurozone increased in the 1980s and 1990s. Mayor investments in European 
countries were made, like the acquisition of Editis in 2008 (the third largest French publishing company).

Compared to Spain, Germany offered in general favourable conditions for businesses' longevity. The economically prosperous reconstruction period after the Second World War was accompanied by the introduction of the so-called "social market economy" guaranteeing personal property and supporting industries in their attempt to realize profits. Subsidies for business activities played some role. The major recipients prior to the unification in 1990 were in agriculture, housing and transport; in industries, weak sectors, such as coal mining, shipping and steel were supported as well as firms situated in West Berlin and along the border to the GDR. More importantly was the creation of an attractive and accepted economic framework. In contrast to the Weimar Republic, the post-WWII capitalistic system was generally accepted by entrepreneurs and managers. The regulative concept of the "social market economy" as a compromise between pure liberal and centrally planned economy has been interpreted as a system, which allowed for growth, profits, and wealth (Giersch, Paqué and Schmieding 1994). The prosperous 1950s and 60s with overall high growth rates, an enlarging social state and the introduction of co-determination to the German economic system eased the opposition of capital and labour. Even though severe changes occurred since the 1970s, for example in the printing industry, the relationship between capital and labour was overall rather harmonious compared to other European countries (Spode et al. 1992; Kittner 2005). Anti-trust legislation, in particular the Act against Restraints on Competition (Gesetz gegen Wettbewerbsbeschränkungen), derived from US pressure after the II World War. It prohibited constraints on competition, especially cartels and abuses of market power, and prevented mergers that created market dominance. 
Decisive for the long-term survival of family firms was also the rich variety in types of ownership and influence that the German corporate law allowed for. The alternative legal forms to the incorporation (Aktiengesellschaft), such as the limited partnership (Kommanditgesellschaft), the private limited liability company (Gesellschaft mit beschränkter Haftung), and different mixed forms, explain why the listed corporation accounts for only a small percentage of German firms to this day (Guinnane et al. 2007; Deutsches Aktieninstitut e.V. 2009; Lamoreaux 2009). Family firms in particular often restrained from going public, which might have facilitated long-term independence and continuous family influence. Bagel remained a private company and never ventured onto the stock market. Deckel, in the much more capital-intensive metal transformation industry, went public in 1973. However, it opted to give out (some) preference shares, which do not grant voting rights to shareholders, as a way to maintain the influence of the founding family (Schürmann and Körfgen 1987).

\section{Inheritance Law}

Finally, in both countries moderate inheritance taxation favoured intra-family successions; albeit changes over time. While these developments are more difficult to trace on the microlevel of the individual case companies (due to privacy concerns by the affected individuals), they are undoubtedly significant for explaining the longevity of family businesses in both countries. In Spain, the legislation between the 1950s and 1978 was clearly very light in terms of taxation of family wealth transmission, and also in terms of transparency and accountability of the economic activity of private firms. This resulted in a lack of control and, also, in positive conditions for the generational transfer of family businesses, in general (particularly in sectors not considered of national interest by the State). This changed after 1978, until the late 1990s, when a tough legislation abruptly rose death duties, to almost 40 
per cent over total value of one person's wealth after death to his/her heirs. This meant a rapid death rate of family businesses in which personal and business wealth had been mixed for decades. This changed after the 1990s decentralization of wealth transfer taxation in regional administrations, and the global expansion of economic activity, which resulted in a diversity of regional conditions and in a general trend of the public administrations towards reduction of taxes burdening wealth transfer within family businesses, as lobbies of family firms managed to have bills approved in which personal and business wealth were to be considered legally different in family firms for tax purposes (Fernández Pérez and Hernández 2010).

In Germany, the taxation of family wealth transmission in the second part of the twentieth century was also moderate and offered different allowable deductions for spouses and children, which resulted in a less transparent system but significantly reduced the net liability. Historically, the German inheritance law interprets possession not as an individual's but as family wealth (Beckert 2008). A descendant was by law obliged to pass a part of his or her possession on to his spouse and children. This regulation can only be explained as a path dependency resulting from decisions and regulations fixed in the $19^{\text {th }}$ century. However, being forced to spread the legal portion equally among descendants may also be interpreted as an obstacle for German family firm's longevity because all descendants needed to be included as beneficiaries.

With the beginning of the twenty-first century, a process of convergence can be observed. Taking the example of a medium-sized incorporated company, the taxation in Germany in 2003 was $6.08 \%$ compared to $4.71 \%$ in Spain, which places both countries among the moderately taxing countries. ${ }^{13}$ For a private enterprise, the tax burden in Spain would be

\footnotetext{
${ }^{13}$ Lesser tax rates can be found in Luxembourg (no taxes) Liechtenstein, Ireland, Switzerland, and the UK; higher rates in Austria, Belgium, France, Sweden, the Netherlands, and Japan.
} 
lighter $(0.16 \%)$ than in Germany $(3.77 \%)$, but other countries, such as Ireland, Luxembourg, and the UK, do not raise taxes at all, while Japan (28.02\%) has significantly higher tax rates (Scheffler, Spengel and Büttner 2004, 970).

These comparisons suggest that in the last two decades taxation policies have been relatively light for German and Spanish family businesses, in international comparison. What we know about this subject indicates the strong influence of regional lobbies of family businesses and politicians in helping achieve relatively light wealth transfer taxes. In Spain, these lobbies combined the interests of local companies and politicians, with the aim to protect employers and employees after the crisis of the 1970s and the impact of new competitors coming from emerging countries during the second wave of globalization that started in the 1980s. The lobbies were able to promote and get approval of new legislation that radically changed inheritance and corporate tax legislations originating in some cases in the eighteenth or nineteenth century, and in other cases in the 1970s crisis, that had two negative effects on wealth transfer and business continuity: the division of wealth after the death of a family member among all legitimate successors, on the one hand; and on the other hand the reduction of individual and collective wealth due to payments of death duties following the death of a family member. After the 1970s crisis these two relatively traditional negative effects of inheritance and corporate tax laws were felt extremely harmful and unjust by family business lobbies, and an obstacle to the opportunities to start or increase internationalization strategies opened up after the 1980s and 1990s. Roca and Planeta were two of the first members of the most important Spanish lobby of family businesses (the Instituto de Empresa Familiar), whose original aim was precisely to fight unfair taxation policies that were an obstacle for the longevity of family businesses in the country (Fernández Pérez and Puig 2009). 


\section{Conclusion}

Family businesses are a dominant form of business ownership in developed and developing countries, and family business studies have emerged in the last decades as an important research field, which attracts scholars from business history, management, organizational behaviour schools, psychology, and economics. Important efforts towards the institutionalization of this research field in the United States and Europe have been developed since the late 1970s, which are contributing to debate definitions, methods, and goals. In these debates about the family business there is general agreement about the fact that the very essence of a family businesses is the willingness to transfer the business to individuals who are culturally defined as kin, whether the kinship ties are of a consanguineous or a spiritual kind. The search for continuity beyond one's life is, therefore, a defining feature of the family business.

Researchers have suggested different models that aim at investigating family firm's longevity. However, most of these attempts are disembedded from a historical as well as a national context and focus instead on the challenges for the internal organization of the family firm. In this article, we contribute to the literature that explores links between issues of corporate governance and the broader historical framework. With this, we make an argument for a more historically sensitive analysis of family business survival which explicitly addresses how different contexts influence family firm behaviour; not just in Germany and Spain but among all family businesses. We posit that any discussion of longevity ought to explicitly include an analysis of the historical context to be convincing. This will also allow for greater cross-fertilization with family business management studies (Wright et al. 2014). We contribute to this discussion with an analysis of the influence, at the microlevel, of three long- 
term external factors _economic development, political context, inheritance law in the analysis of family business longevity.

Our short analysis of the 100 largest family firms in Germany and Spain in 2005 revealed that they differ considerable in their longevity. The figures clearly indicate that today's largest family firms in Germany initiated their competitive advantage and foundations for longevity in the midst of the unification and industrialization process of the country. For Spain, the figures suggest that the largest family firms in 2005 were mostly founded during Franco's dictatorship. Franco significantly restricted private initiative in what military officials considered national interests (heavy industry, energy, telecommunications, and transportation equipment) (Carreras and Tafunell 2004, but allowed the development of private firms in consumer goods industries and in other sectors not considered of strategic interests like publishing (Planeta) or the manufacturing of ceramic and metal sanitary equipment (Roca). This paradox helps explain that in the period of key restrictions for family businesses so many long-standing family businesses were founded in the country.

Looking at the average age of these firms - 83 years in Germany and 41 years in Spain-it might be surprising to note the striking differences. Is not Spain a Mediterranean country where family businesses dominate entrepreneurship, and are thus obstacles for big corporations? Can Germany be considered a Northern European country, where non-family corporations dominate the business landscape in high-tech sectors? However, looking more closely at the exogenous factors we identified, helps to embed the numbers in a historical framework. They fit well with the recent history of German and Spanish family businesses, with the former supported by the political framework of the social market economy and by a favourable economic context until the 1970s, and with the latter heavily influenced first of all 
by the strong limitation of free market forces and the private initiative in some industrial sectors during Franco's dictatorship (1939-1975), and by the strong reduction of taxes burdening the continuity of family businesses in the country after the 1990s (in coincidence with the process of privatization of public firms, integration in European institutions, rapid internationalization of family businesses, and strong support of new regional governments to regionally embedded family firms). That there are today important Spanish family businesses that were created before Franco's dictatorship indicates, on the other hand, the existence of important endogenous factors related to the management of these firms that helped them survive.

In addition to the findings for the two specific countries, the fact that national differences were quite pronounced supports our argument that any longevity model should be grounded in a historical-economic framework. We sought inductively to discover the most important influence factors for longevity. The most important exogenous factors were the industryspecific economic development, the political context, and national regulations in inheritance law. These were closely linked to and helped to explain the endogenous factors for longevity, in particular the development of a new openness to external knowledge and professionals and the level and form of specialization.

Longevity is sometimes perceived as a proxy of entrepreneurial success. In the four large historical family businesses that we have studied longevity is something else: it is the complex result of varying historical opportunities used by several generations of a few entrepreneurial dynasties. Historical opportunities are not controlled by endogenous family strategies, they are path-dependent constructions intertwined with institutional frameworks, in which stability or instability are defined; in which the allocation of strategic tangible and 
intangible resources is made difficult, or easy, to family firms. Schumpeterian entrepreneurship is not a sufficient condition for the creation, and above all, the endurance of family firms.

We have seen in the introductory sections how the enduring institutional support to industrial firms that pioneered the Second Technological Revolution in Germany created favourable conditions for the stability of those firms in times of economic turmoil and political or industrial crisis. The lack, or the discontinuous support, to family controlled industrial firms in Spain, especially in capital intensive sectors and knowledge intensive sectors, made them weaker in domestic and global markets after the II World War. Accessibility to foreign currency, bank or public loans, accessibility to a well-trained labour force, were structurally different -and worse- in Spain after 1939 than in Germany, due to the fundamentally different strategic objectives and organization of the Spanish State between 1939 and 1975. In those years, the most promising venues for creation and endurance of family firms in Spain were in the relatively low capital intensive industries, like in the construction of bath equipment or in the publishing industries. It was in this context that Roca and Planeta could flourish and grow in scale and scope, and due to the limitations of the small Spanish market, and the strong competition in the other Western European markets, they very early targeted Latin American markets for exports first, and outward direct investments, later. More culturally distant markets required higher financial resources, increased risks, and were an option for Spanish family firms in these low capital intensive sectors only after the 1990s, when the Spanish firms had more access to strategically resources they had lacked since the 1930s: capital from global financial sources, and information from global consulting companies. In the case of Germany, family firms were challenged by the external changes in the economic 
environment, in particular after 1970. Many found themselves in a dilemma, when deciding how to incorporate external capital and knowledge, without relinquishing family control. As seen in the case of Deckel, some even reverted to financial instruments, such as preference shares to access the organized capital market without completely giving up family influence. Specialization and global niche markets helped some firms achieve resilience, while others yielded to the pressure. Only a holistic view that incorporates external environmental developments as well as family firms' responses to these changes allows for a historically informed debate of the issue of family business longevity.

\section{Acknowledgment}

Research for this paper has received support from the Spanish research Project "Empredimeinto colectivo, innovación e internacionalización en las empresas españolas de servicios (1900-2017)" (PGC 2018-093971-B-100, Ministerio de Ciencia, Innovación y Universidades/Agencia Estatal de Investigación/Fondo Europeo de Desarrollo Regional,Unión Europea) and funds from an ICREA Academia 2013 award.

\section{Historical Sources}

Newspapers and Magazines

- Wirtschaftswoche

- Managermagazin

- Die Zeit

- Der Spiegel

- El Libro Español

Archives

- Bayerisches Wirtschaftsarchiv München (BWA), N06 Privatarchiv Michael Deckel

- Bayerisches Wirtschaftsarchiv München (BWA), F60 Friedrich Deckel AG 
- Bagel-Archives, accessed via the Rheinisch-Westfälisches Wirtschaftsarchiv zu Köln (RWWA)

- General Administration Archive, Alcalá de Henares, Madrid (Spain).

- Banco de Crédito Industrial Archive, Bilbao (Spain).

\section{References}

Anonymous. 1994. Zwei Kranke im Bett. Der Spiegel. 10: 104-105.

Astrachan, Joseph H., Sabine B. Klein, and Kosmas X. Smyrnios. 2002. "The F-PEC Scale of Family Influence. A Proposal for Solving the Family Business Definition Problem." Family Business Review 15(1): 45-58.

Bähr, Johannes. 2001. Industrie im geteilten Berlin (1945-1990). Die elektotechnische Industrie und der Maschinenbau im Ost-West Vergleich: Branchenentwicklung, Technologien und Handlungsstrukturen. München: Saur.

Bakr Ibrahim, A., J. McGuire, and Khaled Soufani. 2009. "An Empirical Investigation of Factors Contributing to Longevity of Small Family Firms." Global Economy \& Finance Journal 2 (2): $1-21$.

Baumann, Hans. 1965. Maschinenbau. Berlin, München: Duncker \& Humblot.

Beckert, Jens. 2008. Inherited Wealth. Princeton: Princeton University Press.

Berghoff, Hartmut. 2006. "The End of Family Business? The Mittelstand and German Capitalism in Transition, 1949-2000." Business History Review 80 (2): 263-295.

Birley, Sue, Dennis Ng, and Andrew Godfrey. 1999. "The Family and the Business." Long Range Planning 32 (6): 598-608.

Bjuggren,Per-Olof, and Lars-GöranSund. 2001. "Strategic Decision Making in Intergenerational Successions of Small- and Medium-Size Family-Owned Businesses." Family Business Review 14 (1): 11-24.

Capasso, Arturo, Carmen Gallucci, and Matteo Rossi. 2015. "Standing the test of time. Does firm performance improve with age? An analysis of the wine industry." Business History 57 (7): 1037-1053.

Carreras, Albert, and Xavier Tafunell. 2004. Historia económica de la España contemporánea. Barcelona: Crítica.

Cassis, Youssef. 1997. Big Business. The European Experience in the Twentieth Century. Oxford.

Casson, Mark. 1999. "The Economics of the Family Firm." Scandinavian Economic History Review 47 (1): 10-23. 
Chandler, Alfred D. 1977. The Visible Hand. The Managerial Revolution in American Business. Cambridge, MA: The Belknap Press of Harvard University Press.

Chandler, Alfred D. 1990. Scale and Scope: The Dynamics of Industrial Capitalism. Cambridge, MA: The Belknap Press of Harvard University Press.

Chua, Jess. H., James J. Chrisman, and Pramodita Sharma. 1999. "Defining the Family Business By Behavior." Entrepreneurship Theory and Practice 23 (4): 19-39.

Colli, Andrea. 2003. The History of Family Business 1850-2000. Cambridge: Cambridge University Press.

Colli, Aandrea. 2011a. "Business History in Family Business Studies. From Neglect to Cooperation?" Journal of Family Business Management 1 (1): 14-25.

Colli, Andrea 2011b. "Family Firms in European Economic History." In Doing Succession in Europe. Generational Transfers in Family Businesses in Comparative Perspective, edited by I. Stamm, P. Breitschmid and M. Kohli, 29-58. Zürich: Schulthess.

Colli, Andrea, Paloma Fernández Pérez, and Mary B.Rose. 2003. "National Determinants of Family Firm Development? Family Firms in Britain, Spain, and Italy in the Nineteenth and Twentieth Centuries." Enterprise \& Society 4 (1): 28-64.

Colli, Andrea, and Mary B. Rose. 2007). "Family Business." In The Oxford Handbook of Business History, edited by G. Jones and J. Zeitlin, 194-218. Oxford: Oxford University Press.

Daunton, M. J. 1988. "Inheritance and Succession in the City of London in the Nineteenth Century." Business History 30 (3): 269-286.

Deutsches Aktieninstitut e.V. 2009. DAI-Factbook 2009. Statistiken, Analysen und Graphiken zu Aktionären, Aktiengesellschaften und Börsen. Frankfurt/Main.

Dyck, Bruno, Michael Mauws, Frederick A. Starke, and Gary A. Mischke. 2002. "Passing the Baton. The Importance of Sequence, Timing, Technique and Communication in Executive Succession." Journal of Business Venturing 17 (2): 143-162.

Ehrhardt, Olaf, Eric Nowak, and Felix-Michael Weber. 2006. "Running in the Family" The Evolution of Ownership, Control and Performance in German Family-Owned Firms, 1903-2003 (Swiss Finance Institute Research Paper Series No 06-13). Zürich.

Eichengreen, Barry J. 2008. Globalizing Capital. A History of the International Monetary System. Princeton, N.J.: Princeton University Press.

Fahed-Sreih, Josiane, and Salpie Djoundourian. 2006. "Determinants of Longevity and Success in Lebanese Family Businesses. An Exploratory Study." Family Business Review 19 (3): 225-234.

Fear, Jeffrey. 2005. Organizing Control: August Thyssen and the Construction of German Corporate Management. Cambridge, MA: Harvard University Press. 
Fernández-Moya, María. 2015. "La internacionalización de los editores. Los mercados exteriores." In Historia de la Edición en España (1939-1975), edited by Jesús Martínez Martín, 575-595. Madrid, Marcial Pons.

Fernández-Moya, María.2012. "Creating Knowledge Networks: Spanish Multinational Publishers in Mexico". Business History Review 86 (1): 69-98.

Fernández-Moya, María. 2009. "Multinacionales del castellano. La internacionalización del sector editorial español." Revista de Historia Industrial 40:23-50.

Fernández-Roca, Francisco Javier, Jesús D. López-Manjón, and Fernando Gutiérrez-Hidalgo.2014. "Family Cohesion as a Longevity Factor of Business with Intergenerational Transmission." Enterprise \& Society 15 (4): 791-819.

Fernández Pérez, Paloma. 1997. El rostro familiar de la metrópoli: redes de parentesco y lazos mercantiles en Cádiz, 1700-1812. Madrid, Málaga, Spain: Siglo Veintiuno de España Editores, Unicaja.

Fernández Pérez, Paloma, and Pablo Díaz. 2016. "Between power and the market: an approach to the historical evolution of large family businesses in Spain in the twentieth century." In Evolution of family business: continuity and change in Latin America and Spain, edited by P. Fernández Pérez, and Andrea Lluch, 217-237. Cheltenham, UK ; Northampton, MA: Edward Elgar Publishing.

Fernández Pérez, Paloma, and Aurelia Hernández.2010. "The Role of the State in the Promotion of Entrepreneurship among Family Businesses. The Case of Spain in a Long-Run Perspective." Entrepreneurial History Discussion Papers, online: http://www.ehdp.net/p005.html (accessed 4 October 2010) 5.

Fernández Pérez, Paloma, and Andrea Lluch, eds. 2016. Evolution of family business: continuity and change in Latin America and Spain. Cheltenham, UK ; Northampton, MA: Edward Elgar Publishing.

Fernández Pérez, Paloma, and Nuria Puig. 2009. "Global Lobbies for a Global Economy. The Creation of the Spanish Institute of Family Firms in International Perspective." Business History 51 (5): $712-733$.

Fernández Pérez, Paloma, and Nuria Puig. 2007."Bonsais in a Wild Forest? A Historical Interpretation of the Longevity of Spanish Large Family Firms." Revista de Historia Económica Journal of Iberian and Latin American Economic History vol. XXV (3): 459-498.

Fernández Pérez, Paloma, ed. 2013. La profesionalización de los negocios familiares en España y México. Madrid: LID. 
Fernández Pérez, Paloma, and Andrea Colli, eds. 2013. The Endurance of Family Businesses. A Global Overview. Nueva York: Cambridge University Press.

Fernández Pérez, Paloma. 2015. "Impacto de la crisis en las grandes empresas familiares del mundo. Una primera aproximación cuantitativa para 11 países." AEHE Working Paper 1512. Available at https://econpapers.repec.org/paper/ahedtaehe/1512.htm

Friedrich Deckel München, ed. 1978. 75 Jahre Deckel. München: Deckel.

Giersch, Herbert, Karl-Heinz Paqué, and Holger Schmieding. 1994. The Fading Miracle. Four Decades of Market Economy in Germany. Cambridge: Cambridge University Press.

Goody, Jack, Joan Thirsk, and E. P. Thompson. 1976. Family and inheritance: rural society in Western Europe, 1200-1800. Cambridge Eng.; New York: Cambridge University Press.

Goto, Toshio. 2006. "Longevity of Japanese Family Firms." In Handbook of Research on Family Business, edited by P. Z. Poutziouris, K. X. Smyrnios, and S. B. Klein, 517-534. Cheltenham und Northampton: Edward Elgar Pub.

Guinnane, Timothy, Ron Harris, Naomi R. Lamoreaux, and J.-P. Rosenthal. 2007. "Putting the Corporation in its Place." Enterprise \& Society 8 (3): 687-729.

James, Harold. 2006. Family Capitalism: Wendels, Haniels, Falcks, and the Continental European Model. Cambridge, MA: The Belknap Press of Harvard University Press.

Kittner, Michael. 2005. Arbeitskampf. Geschichte - Recht - Gegenwart. München.

Krogh, H. 1987. "Hürdenlauf mit gutem Ende." manager-magazin 17 (1): 69-76.

Kuratko, Donald F., H. B. Foss, and L. L. VanAlst. 1994. "IRS Estate Freeze Rules. Implications for Family Business Succession Planning." Family Business Review 7 (1): 61-71.

La Porta, Rafael, Florencio Lopez-de-Silanes, and Andrei Shleifer. 1999. "Corporate Ownership Around the World." Journal of Finance 54 (2): 471-517.

Lamoreaux, Naomi R. 2009. "Scylla or Charybdis? Historical Reflections on Two Basic Problems of Corporate Governance." Business History Review 83:9-34.

Lamparter, D. H. 1993. Auf der Suche nach dem Dreh. Die Zeit. 27.

Lorandini, Cinzia. 2015. "Looking beyond the Buddenbrooks syndrome: the Salvadori Firm of Trento, 1660s - 1880s." Business History 57 (7): 1005-1019.

Lubinski, Christina. 2010. Familienunternehmen in Westdeutschland: Corporate Governance und Gesellschafterkultur seit den 1960er Jahren. München: C.H.Beck.

Lubinski, Christina. 2011. "Path Dependency and Governance in German Family Firms." Business History Review 85 (4): 699-724.

Lubinski, Christina, Jeffrey R. Fear, and Paloma Fernández Pérez, eds. 2013. Family Multinationals: Entrepreneurship, Governance, and Pathways to Internationalization. New York: Routledge. 
Mackie, Robin. 2001. "Family Ownership and Business Survival: Kirkcaldy, 1870-1970." Business History 43 (3): 1-32.

Mandelbaum, Leonard. 1994. "Small Business Succession. The Educational Potential." Family Business Review 7 (4): 369-375.

Melin, Leif, Mattias Nordqvist, and Pramodita Sharma, eds. 2013. The Sage handbook of family business. Thousand Oaks, CA: SAGE Publications.

Miller, Danny, and Isabelle Le Breton-Miller. 2005. Managing for the Long Run: Lessons in Competitive Advantage from Great Family Businesses. Boston, MA: Harvard Business School Press.

Napolitano, Maria R., Vittoria Marino, and Jari Ojala. 2015. "In search of an integrated framework of business longevity." Business History 57 (7): 955-969.

Nordlund Edvinsson, Therese. 2016. "Standing in the shadow of the corporation: women's contribution to Swedish family business in the early twentieth century." Business History 58 (4): $532-546$.

Ortega, Juan, and Angel Hermosilla. 2002. Cincuenta años del CEAM y de la metalurgia catalana. Barcelona: CEAM.

Perricone, Philip J., John R. Earle, and Ian M. Taplin 2001. "Patterns of Succession and Continuity in Family-Owned Businesses. Study of an Ethnic Community." Family Business Review 14 (2): 105-121.

Riviezzo, Angelo, Mika Skippari, and Antonella Garofano. 2015. "Who wants to live forever: exploring 30 years of research on business longevity." Business History 57 (7): 970-987.

Sasaki, Innan, and Hidekazu Sone. 2015. "Cultural approach to understanding the long-term survival of firms - Japanese Shinise firms in the sake brewing industry." Business History 57 (7): 10201036.

Scheffler, W., C. Spengel, and T. Büttner. 2004. Erbschaftsteuerbelastung im internationalen Vergleich. Baden-Baden: Nomos.

Schulze, Max-Stephan, ed. 1999. Western Europe. Economic and Social Change Since 1945. London: Longman.

Schürmann, W., and K. Körfgen. 1987. Familienunternehmen auf dem Weg zur Börse. Ein Leitfaden für potentielle Börsenkandidaten mit Beispielen aus der Praxis. München: C. H. Beck.

Sharma, Kamal R., and Mukund R. Dixit. 2018. "Longevity challenges and leadership interventions: Strategy journeys of two Indian banks." Business History 60 (2): 178-201.

Sharma, Pramodita, and Carlo Salvato 2013. "Family firm longevity: A balancing act between continuity and change." In A global revolution: The endurance of large family businesses 
around the world, edited by P. Fernández Pérez and A. Colli, 34-56. Cambridge, UK: Cambridge University Press.

Spode, H., H. Volkmann, G. Morsch, and R. Hudemann. 1992. Statistik der Arbeitskämpfe in Deutschland. Deutsches Reich 1936/37, Westzonen und Berlin 1945 - 1948, Bundesrepublik Deutschland 1949 - 1980. Sankt Katharinen: Scripta-Mercaturae-Verl.

Spur, G. 1991. Vom Wandel der industriellen Welt durch Werkzeugmaschinen. Eine kulturgeschichtliche Betrachtung der Fertigungstechnik. München, Wien: Fachbuchverlag Leipzig.

Stamm, Isabell, and Christina Lubinski. 2011. "Crossroads of Family Business Research and Firm Demography. A Critical Assessment of Family Business Survival Rates." Journal of Family Business Strategy 2 (3): 117-127.

Tàpies, Josep. 2011. "Empresa familiar: un enfoque multidisciplinary." Universia Business Review 32: $12-25$.

Tàpies, Josep. 2009. Empresa familiar: ni tan pequeña, ni tan joven. Barcelona: Fundacion Jesus Serra.

Tàpies, Josep, and María Fernández Moya. 2012. "Values and longevity in family business: evidence from a cross-cultural analysis." Journal of Family Business Management 2 (2): 130-146.

Temin, Peter. 1995. "The 'Koreaboom' in West Germany. Fact or Fiction?" Economic History Review 48 (4): 737-753.

Ward, John. L. 1987. Keeping the Family Business Healthy. How to Plan for Continuing Growth, Profitability, and Family Leadership. San Francisco: Jossey-Bass.

Wieandt, A. 1994. "Innovation and the Creation, Development and Destruction of Markets in the World Machine Tool industry." Small Business Economics 6:421-437.

Wright, Mike, JamesJ. Chrisman, Jess H. Chua, and Lloyd P. Steier. 2014. "Family Enterprise and Context." Entrepreneurship Theory and Practice 38 (6): 1247-1260

Yacob, Shakila. 2012. "Trans-Generational Renewal as Managerial Succession: The Behn Meyer Story (1840-2000)." Business History 54 (7): 1166-1185.

\footnotetext{
This is an Open Access article distributed under the terms of the Creative Commons Attribution-Non-Commercial-No Derivatives License (http://creativecommons.org/licenses/by-nc-nd/4.0/), which permits non-comercial re-use and distribution, provided the original work is properly cited, and is not altered or transformed in any way.
} 